\title{
CD REVIEWS
}

BENJAMIN: Palimpsests ${ }^{1}$; At First Light ${ }^{1}$; Sudden Time ${ }^{1}$; Olicantus $^{2}$. Ensemble Modern, Ensemble Modern Orchestra, c. ${ }^{1}$ George Benjamin, ${ }^{2}$ Oliver Knussen. Nimbus NI 5732.

Nimbus's ongoing support for George Benjamin continues with a disc of live performances recorded over the last decade. The programming of two recent compositions - Palimpsests and Olicantus - with key works from earlier in Benjamin's career allows one to perceive how his compositional style has evolved.

Common to the works with which Benjamin first came to prominence is an astounding command of instrumental and harmonic colour. Such qualities, seamlessly incorporated into a compelling and thoroughly convincing musical design, are abundant in At First Light, the earliest piece represented on the disc. The central conceit of the work, to 'melt' sharply defined ideas into a 'flowing, nebulous continuum of sound', 'was inspired by a late painting by Turner. The timbral and textural manipulations by which this is achieved are constantly dazzling; some two decades after its composition, At First Light continues to sound fresh and vital.

The difficulties Benjamin faced in the composition of Sudden Time, in which he attempted to 'liberate form by writing in a much more linear way than before' may well explain its lengthy gestation (around a decade). ${ }^{2}$ Here, the underlying metaphor is that of (musical) time as being something pliable, able to be stretched or compressed. What one actually hears is a musical discourse in which different strata move at different speeds (or give the impression of contrasting states of motion); from this, points of stability emerge only to be engulfed soon after. The huge orchestral resources at Benjamin's disposal are treated with utmost sensitivity in order to colour and clarify the unfolding material. One cannot underestimate the significance of Sudden Time in Benjamin's output: the technical solutions it provided to previously intransigent compositional problems seem to have allowed him to refine his distinctive voice in a string of major works over the last decade.

\footnotetext{
${ }^{1}$ George Benjamin, George Benjamin (London: Faber and Faber, 1997), p. 69

2 Ibid., p. 78.
}

Time also figures, albeit obliquely, in the conception of Palimpsests. A palimpsest is a manuscript in which the original text has been partially obscured and put into new contexts by the addition of one or more overlaid texts. However, Benjamin's alternative analogy of a cityscape, in which the addition of new buildings serves to throw the older constructions into new relief, seems to me more pertinent in understanding what is happening in the music. In a cityscape, as one's perspective changes, so too do the relationships between old and new: a building previously hidden from one angle can suddenly become revealed. Equivalently, Benjamin's musical argument is not solely the overlaying of different musics (as would be the case with a palimpsest), but rather a study of how these musics interact and force reinterpretations of one another. A polyphonic clarinet song announced at the opening of the work provides the original 'text' which is continually disrupted and modified by new material; each subsequent presentation bears the traces of this engagement. The second movement, though more expansive, has a similar interaction between contrasting strata. As with At First Light and Sudden Time, Palimpsests demonstrates how an abstract extramusical idea can be transformed into a compelling and vividly realized musical design.

Olicantus, written as a 50th-birthday present for Oliver Knussen, is by comparison, much more modest in scope than the other offerings on the disc. Unlike At First Light, which employs a similar-sized ensemble, the concentration is on the lower registers of instruments: there is little of the brilliance of the earlier work. As with Palimpsests, the opening material is presented on clarinets (here, bass clarinets), providing a text that gains accretions and additional layers, without ever sacrificing its identity.

Benjamin has recorded both At First Light and Sudden Time before; these more recent performances make for an interesting comparison. ${ }^{3}$ Given the array of timbres that Benjamin makes use of in both of these works, it is surprising to note that the instrumental colours of these later recordings are not as vivid as the

\footnotetext{
3 Available on Nimbus NI 5643 (with the London Sinfonietta) and NI 5505 (with the London Philharmonic Orchestra) respectively.
} 
earlier ones: the sounds are better blended, less distinct. But what one loses in sharp definition is gained in the greater sense of assurance: the performances are tauter and more focused, and the ensemble playing more accurate. Benjamin's reading of Palimpsests is similarly compelling. However, I found the clarinet's audible keyclacking at the start of Palimpsests and Olicantus a distraction, and my stereo had problems coping with the extremities of levels: I had to keep adjusting the volume in order to hear the quiet passages and avoid being deafened by the louder ones. But even with these quibbles, this remains a welcome and highly recommended disc.

Edward Venn

PETRASSI: Concertos for Orchestra Nos. 1-8. Netherlands Radio Symphony Orchestra c. Arturo Tamayo. Stradivarius STR 33700 (2-CD set).

When does a concerto for orchestra become a symphony? What, really, is the difference between the two forms? Both are large-scale genres, often - though not necessarily showcasing either the orchestra as a whole or individual players or sections within it. Bartók, creator of still the most-performed orchestral concerto, certainly highlighted the display purpose as the raison d'etre behind his choice of title, but then his style of symphonism-by-stealth made the concerto tag innately more apt. Bartók's Concerto, like Lutoslawski's, does not feel like a symphony - any more than either of Hindemith's: one from 1925, an updated concerto grosso with which he invented the form, or the variation-form Philharmonic Concerto (1932). ${ }^{4}$ Hindemith is especially pertinent when discussing the concerti of Goffredo Petrassi (1904-2003), since it was the example his 1925 Concerto that prompted the composition of the Italian's first (to which, incidentally, he never assigned a number) in 1933-4. It may also account for the notably Hindemithian cast of that work's themes and design: a bracing opening Allegro (in which there is a deal of Stravinsky to be heard and, here and there, of Honegger) and a march finale framing a less impersonal Adagio, the longest in duration of the three. If the Roman's own voice had not yet fully formed, it bore a distinctive accent that later works would refine.

Petrassi may not have written the most concertos for orchestra - Hovhaness has that

${ }^{4}$ Composed for the Berlin Philharmonic. Likewise Malcolm Arnold's identically-named piece written decades later to celebrate the Manchester-based BBC orchestra. honour, I think - but he was undoubtedly its most consistent exponent. Yet it took him another 17 years to pick up the form again: and then the flood-gates opened with five concertos in six years. If No.1 put form over virtuosic display, the single-span Second (1951) married the two most convincingly. Commissioned by Paul Sacher for a classically sized band, Petrassi created a highly cogent design that, were it to be called symphony, would not raise a single eyebrow. The frame of reference is now wider, with elements of Busoni and Karl Amadeus Hartmann - whose Second Symphony is also in a single movement ${ }^{5}$ suffusing he score; but over and above one hears Petrassi's own voice clearly for the first time in the cycle. These traits are continued and embellished further in Récréation concertante (1952-3, subtitled Third Concerto), which has an altogether spikier feel to the thematic material (featuring a 12-note row) and to the orchestration. Here Stravinskyan rhythmic élan was married to Busoniesque 'Young Classicality' to produce a lean litheness of sound (occasionally reminiscent of Roussel's later music) that marked this concerto as the most satisfying of the series to date.

But in the Fourth (1954), scored for strings alone, Petrassi topped it. The virtuosity of its writing is apparent from the opening bars, with the high violin lines entering after the music has emerged quietly from the depths. Concerto or no, it has the breadth - and breath - of a real symphonist. Yet, ironically, this is Petrassi's most Bartókian score: many commentators have noted its kinship to the Music for strings, percussion and celesta. ${ }^{6}$ (However, there is also another parallel with Hartmann, whose Fourth Symphony is for string orchestra.) The music traverses some extraordinarily wide-ranging tonal and textural vistas, all the more remarkable, perhaps, for its monochrome medium - though it is by no means unique in transcending that limitation - and the rigour of its often dodecaphonic material. Almost as soon as he had completed this wonderful piece, Petrassi embarked on a Fifth, completed in 1955, which astonishes by being so utterly different in form and feel from its predecessor. It sounds like music from another world; there is a far lesser stylistic divide between the first two concertos than the Fourth and Fifth, which really do sound 17 years apart!

\footnotetext{
Or if not Hartmann, a mutation of Hindemith along very similar lines.

${ }^{6}$ Including Paolo Petazzi, in the set's accompanying booklet (which could have done with some closer proof-reading), and Malcolm MacDonald, in his excellent 'Petrassi and the Concerto Principle (II)', Tempo Vol.57 no.225, pp. 9-22. Though no-one, as far as I know, has noted how the brief Sereno third section foreshadows middle-period Robert Simpson!
} 
Uniquely in the series, the Fifth is cast as a diptych, the first movement moving from an initial Molto moderato tempo through various vicissitudes to a closing spectral Presto. The longer second span arches from Andantino to Lento e grave by way of a Mosso, con vivacità central episode. In many respects, Petrassi's resumption of writing orchestral concertos arose from a need to replace overtly theatrical composition - that had come to the fore in his music in the 1940s but he eschewed it from 1950 - with abstract dramas every bit as compelling as those for the stage. The Fifth Concerto, for all its compositional virtuosity and surface brilliance, has a darker undertow than its predecessors. Petrassi was as alive to the issues of the wider world around him as any composer of his time, but whereas in Concertos Nos 2-4 he concerned himself with matters musical, as if as an escape to the events of the recent past, in the Fifth and its successor he seems finally to have decided to meet these issues head-on, albeit sublimated in orchestral panoplies of remarkable sophistication. Curiously, both the Fifth and Sixth (1956-7) were composed to mark institutional anniversaries, respectively the 75 th of the Boston Symphony Orchestra and the 10th of the BBC Third Programme.

No. 6 returned to the single-span format, but its primary title of Invenzione concertata conveys more accurately its more sectional construction, the five parts dovetailing into each other. However, despite this and the sometimes fragmentary, even eruptive, orchestral textures (another feature carried over from No. 5), this is one of Petrassi's most closely argued and concentrated scores. (It is by some way the shortest of the concertos.) Its level of invention is correspondingly high, creating a fantastical sound-world that is rivetting on first acquaintance yet is still yielding up secrets on the tenth hearing. In the booklet essay, Paolo Petazzi calls the Sixth an 'arrival point' and it is the pinnacle of the series, with a feeling of closure in its final bars. Had Petrassi stopped the sequence here, his achievement as - ironically - Italy's foremost symphonist, outstripping even Malipiero, would be clear for all to hear. But in 1961-4 and again in 1970-2 he produced two further concertos that took up from where the Sixth left off. And there may be another faint parallel with Hartmann here, whose own Sixth Symphony -arguably the peak of his career - had marked, just a few years earlier, the end of a sustained period of symphonic composition, eventually succeeded by two isolated further symphonies that benefited from its liberation of expression. Petrassi may indeed, as Petazzi notes, have intended the
Seventh (more clearly cast in an unbroken sequence of prologue, four inventions and epilogue) to round off the cycle, even quoting the opening and closing notes of the First, but a commission from the Chicago Symphony Orchestra for Carlo Maria Giulini was too much to resist. In his Eighth and last Concerto Petrassi reverted to the First's three-movement design, broadly Allegro-Adagio-Allegro (though there are no tempo indications beyond metronome markings, and internally the processes are entirely different, products of a lifetime of experience). This, much more than the Seventh, marks a fitting conclusion to the cycle, though its soloistic use of percussion (played on this new recording by Ruud Stotijn, Vincent Cox, Maarten Smit and Mark Haeldermans) might have pointed to a new departure had the urge to write a Ninth borne fruit.

These new recordings represent the first cycle by a single conductor and orchestra, since Zoltán Peskó's pioneering and much re-issued set, currently available on 3 discs from Warner-Fonit, was made using three different orchestras. ${ }^{7}$ Stradivarius's newcomer scores straight off in being able to place the eight works on just two well-filled discs (running to $81^{\prime} 12^{\prime \prime}$ and $78^{\prime}$ ) respectively. This is due partly to Tamayo's often snappier tempi - just compare his account of the First with Peskó's - and probably to an effort of will to squeeze it all on to two discs. There is no sacrifice in sound quality and the Dutch recordings have great presence, benefitting from a uniform acoustic. However, it must be said that the drier, albeit variable sonic pictures from the Peskó discs do suit Petrassi's music rather better than the perhaps over-warm sound from Stradivarius. In terms of performances, there is no doubt that Tamayo's new set is superior, despite Peskó's authority as a student of the composer. Broadly, the latter conductor's recordings with the BBC Symphony Orchestra fare pretty well against the new accounts, though Tamayo's seem to me better focussed and prepared. The two Philharmonia Hungarica recordings are in no way inadequate but, again, the Netherlands Radio players have the edge. The main area where Peskó's set is let down is with the performance of the Fifth and especially Sixth Concertos: by comparison to Tamayo's these seem mere play-throughs. The orchestral balance is more realistic on the new discs; but the most palpable gain is the greater understanding of Petrassi's style that the Dutch players show -

\footnotetext{
7 Concertos 1, 2, 7 and 8 with the BBC Symphony Orchestra, Nos. 3 and 4 with the Philharmonia Hungarica, Nos 5 and 6 with an under-rehearsed Milan Radio Orchestra.
} 
something even the BBC Symphony Orchestra in 1978 could only approximate. To summarize, then, this new set is nothing short of a triumph.

Guy Rickards

JOHN ADAMS: On the Transmigration of Souls. New York Choral Artists, Brooklyn Youth Chorus, New York Philharmonic c. Lorin Maazel. Nonesuch 7559798162.

Commissioned by the New York Philharmonic in commemoration of the first anniversary of the World Trade Center attacks, On the Transmigration of Souls was premièred on 19 September 2002 in Avery Fisher Hall, Lincoln Center, as the opening work of the orchestra's 2002-3 season. Scored for orchestra, chorus, children's choir and pre-recorded multi-channel soundtrack, the 25-minute work received the 2003 Pulitzer Prize for Music.

With an oeuvre that includes Nixon in China, The Death of Klinghoffer and El Dorado, Adams is clearly predisposed to mining subjects from contemporary history - indeed his third opera, Doctor Atomic, due to receive its world premiè re in October 2005 in San Francisco, focuses on the final days leading up to the explosion of the first atomic bomb - but nothing could quite have quite him for this latest commission.

For On the Transmigration of Souls Adams assembles a text comprised of three main sources: a recitation of the names of victims, brief fragments taken from missing person signs that had been posted around Ground Zero by the families and friends of the victims, and personal reminiscences drawn predominantly from interviews in the New York Times' 'Portraits of Grief' series.

In its superimposition of pre-recorded street sounds (city traffic, voices, footsteps, sirens) and recitation of victims' names with the live elements of children's chorus, adult chorus and orchestra, the work's subtle blending of sound sources and multiplicity of event evokes the compositional technique of Cage's Roaratorio, albeit creating an entirely different emotional response. Adams had already employed the very particular timbral quality of the children's chorus in his oratorio El Niño. But whereas in that work their voices only appeared at the very end of the piece, here they are very much centre-stage - it is the stark contrast between the children's chorus and adult chorus that gives the work much of its specific flavour.

By blurring the boundaries of the concert hall and the everyday world beyond its walls, Adams creates a vast reverberating space that serves to embrace both the souls of the dead and the changed lives of those left behind - past and present brought movingly together. The opening eight minutes of music, in which the various layers appear to float and collide freely in space, possesses an almost hallucinatory quality and is one of the finest passages to come from the composer's pen. The protracted climax that erupts at the two-thirds point ('I loved him from the start ... I wanted to dig him out. I know just where he is') is absolutely crushing.

The sound quality of the live Nonesuch recording is exceptionally good. In the role of soundscape designer and sound engineer literally enveloping the audience with the prerecorded elements - special plaudits must go to Mark Grey.

Peter Quinn

EGON WELLESZ: Vorfrühling; Leben, Traum und Tod; Lied der Welt; Sonette der Elizabeth Barrett Browning; Ode an die Musik; Vision; Symphonischer Epilog. Regina Klepper (sop), Sophie Koch (mezzo), Deutsches Symphonie-Orchester Berlin, c. Roger Epple. Capriccio 67077.

WELLESZ: Symphonies Nos. 1 and 8; Symphonischer Epilog. Radio Symphonieorchester Wien, c. Gottfried Rabl. CPO 999998-2.

WELLESZ: Symphonies Nos. 2 and 9. Radio Symphonieorchester Wien, c. Gottfried Rabl. CPO 999997-2.

WELLESZ: Prosperos Beschwörungen; HONEGGER: Symphony No. 5; STRAVINSKY: Le Sacre du printemps; JANÁČEK: Sinfonietta; WEBERN: Passacaglia; Six Movements op. 6; BERG: Der Wein; SCHOENBERG: Pelleas und Melisande; SCHMIDT: Symphony No. 2. Vienna Philharmonic c. Haitink, Ansermet, Markevitch, Kubelik, Mehta, Dorov, Bohm, Leinsdorf. Andante AND4080.

'Continental Britons: The Emigré Composers'. WELLESZ: Octet; Geistliches Lied; Kirschblutenlieder. SPINNER: Zwei Kleine Stücke. GOLDSCHMIDT: Fantasy for oboe, cello and harp; The Old Ships. GELLHORN: Intermezzo for violin and piano. TAUSKY: Coventry. GÁL: Sonata in B flat minor for violin and piano, op. 17; Fünf Melodien. SEIBER: Sonata for violin and piano. REISENSTEIN: Quintet for flute, oboe, clarinet, bassoon and horn. RANKL: Two songs from War, op. 10; The Whim. Ensemble Modern, Frankfurt, with Christian Immler (bar), Erik Levi (pno), Nurit Pacht (vln), Konstantin Lifschitz (pno), Paul Silverthorne (vla). Nimbus NI 5730/ 1 (2-CD set). 
Egon Wellesz (1885-1974) suffered decades of neglect in his later years, especially in Britain, where he settled in 1938 as an exile from Nazioccupied Austria. The ever-expanding Wellesz discography is one of the most heartening developments in the record industry in recent years. There is no room for complacency, however: concert performances of his works in this country are still depressingly rare and it is worth noting that, apart from the Nimbus CD specifically devoted to émigré composers, all of the above releases originated outside the UK.

The Capriccio disc makes an excellent starting point for anyone wishing to explore the Wellesz sound-world, providing examples from his early Impressionist phase, through his mid-period postRomantic era and his glorious Indian summer characterized by a return to his Second Viennese School roots (Wellesz studied with Schoenberg 1904-06). Vorfrühling (1912) is a lusciously-scored symphonic poem for large orchestra with bittersweet harmonies revealing the influence of Debussy. It is a half-brother to Webern's Im Sommerwind and merits comparable popularity. The Sonnets of Elizabeth Barrett Browning for soprano and strings, from 1934, serve notice of Wellesz's skill in enhancing English texts, something which was to come to fruition ten years later in his gloriously dramatic setting of Gerard Manley Hopkins's The Leaden Echo and the Golden Echo for soprano and ensemble. The disc also provides a representative selection from the composer's tougher, harmonically adventurous final years, including the powerfully epigrammatic Vision from 1966 and the grippingly Expressionist Symphonischer Epilog (1969). This release, with subtle and responsive playing throughout from the DSO, Berlin under Roger Epple, is very highly recommended.

Symphonischer Epilog also appears on the latest issue from CPO's Wellesz symphony cycle with the Radio Symphonieorchester Wien under Gottfried Rabl. In this performance, the conception is more urgent and compelling, with taut and brutal climaxes. Rabl also applies this brisk, no-nonsense approach to the symphonies. The tautly-argued Eighth Symphony from 1970 benefits from such a cogent, clear-sighted view. On the other hand the First Symphony, composed in 1945 after a five-year creative impasse brought on by enforced exile, ideally needs more time to breathe, especially in the genuinely sublime concluding slow movement. However, Rabl does sound much more emotionally committed here than he does elsewhere in the cycle.

In the Second and Ninth Symphonies, there is occasionally a feeling of clinical efficiency in the habitual observance of quick tempi. Rabl's dryeyed approach certainly helps to avoid any sense of special pleading, but the Second Symphony's Scherzo, for example, is such a charming invention, with its knowingly academic fugato main subject and artlessly rustic Trio, that one longs for a less analytical, unyielding conception. The Ninth Symphony is a worthy farewell to orchestral writing from Egon Wellesz; here Rabl and his Viennese players find moving echoes of earlier Ninths from Bruckner and Mahler, especially in the anguished concluding Adagio. Both CPO discs deserve praise as dependable introductions to Wellesz's symphonic legacy, whilst leaving the way wide open for more charismatic readings to reveal further insights. I hope Rabl, who makes a trustworthy if at times inflexible guide, will return to these intensely human scores again, his interpretations deepened by familiarity and experience.

Prosperos Beschwörungen (1936), five symphonic pieces after The Tempest, was the last major piece Wellesz wrote before emigrating and its Shakespearian provenance seems with hindsight to presage his future career as an Oxford University tutor. This 3-CD set from Andante contains a live recording of the work with Haitink conducting the Vienna Philharmonic at the 1985 Salzburg Festival. It's a surprisingly rough-hewn reading from these usually ultra-sophisticated musicians, but Haitink is audibly alert to the many subtleties of Wellesz's masterly orchestration. The only alternative recording - by the Vienna Radio Symphony Orchestra under Gerd Albrecht on Orfeo (C 78981A), coupled with the gritty Violin Concerto - is more polished, but much less gripping.

The Nimbus collection, entitled 'Émigré Britons', is a treat, packed with long-forgotten chamber works bearing the stamp of genuine craftsmanship. Wellesz is represented by his sunny, liltingly Schubertian Octet, perhaps his most immediately attractive instrumental work. It is a wonderfully ripe, lyrical and dramatic piece whose Austrian charm and fastidiousness would grace the programme of any chamber concert; it receives a reading of unforced charm and wit and ought to win the composer many new friends. The other items on the 2-disc set are just as invaluable, not least a rare opportunity to hear some brief excerpts from the music of Karl Rankl, another Schoenberg disciple whose eight symphonies shamefully still remain unrecorded.

All these recent Wellesz releases are essential in furthering our understanding of the expressive range of a man who was more widely regarded in England as a scholar than a composer. There is 
some way to go, however, before his hugely impressive output is adequately represented on CD. For example, Wellesz's nine skilfullywrought string quartets, which cover six decades of his creative life, all demand to be heard. After he completed the Ninth Quartet in 1966, he went on write a further trio of concentrated chamber works - three sets of four pieces - which match the late symphonies in their powerful integrity: Vier Stücke für Streichquartett (1968), Vier Stücke für Streichtrio (1969) and Vier Stücke für Streichquintett (1970). These merit urgent attention, along with his operas, Die Prinzessin Girnara (1920), Alkestis (1923), Scherz, List und Rache (1927) and the Straussian Incognita (1950). ${ }^{8}$ Until these pieces have been committed to disc, along with the early ballets Das Wunder der Diana (1917), Persisches Ballett (1920), Achilles auf Skyros (1921), the midperiod masterpiece The Leaden Echo and the Golden Echo (1944) and the late choral works Mirabile Mysterium (1967) and Canticum Sapientiae (1968), we cannot claim to have a truly representative selection of Wellesz's oeuvre on record from which to begin to measure the full extent of his creative achievement.

Paul Conway

CYRIL SCOTT: Symphony No. 3 The Muses; Piano Concerto No. 2; Neptune. Howard Shelley (pno), Huddersfield Choral Society, BBC Philharmonic, c. Martyn Brabbins. Chandos CHAN 10211.

In a recent lecture Lukas Foss stated 'I believe that the only criterion for making an intelligent evaluation of a piece of music is: does it make you want to hear it again?' Since the raison d'être of the $\mathrm{CD}$ is repeated hearings, a positive review would have to state reasons why the music in question reveals different aspects every time, compelling one to return to it. Such a case can definitely be made for this new release of works from Cyril Scott's middle and late periods. Far from the rather soupy impression that certain of the composer's minor works give, these large-scale works reveal toughness, consequence and strong mental discipline, together with great passion.

Toughness, discipline? Can we be talking about the same composer? The early potboilers notwithstanding, Scott's 70-year composing career does indeed show a ripening, deepening, that becomes ever more apparent with each new major work. Take the 1980s cassette release ('John Ireland

\footnotetext{
${ }^{8}$ On some of these works see Philip Ward's article 'Egon Wellesz: an Opera Composer in 1920s Vienna' in Tempo 219 (January 2002), pp.22-28-(Ed)
}

and Friends') of the late Piano Sonata No. 3 (1956), beautifully performed by Eric Parkin. This is a highly original and convincing work by the nearly 80 -year-old Scott. One of the finest British postwar piano works, it certainly rewards repeated hearings. Or the orchestral music recorded by Peter Marchbank and the S.A.B.C. Symphony on Marco Polo. Thinking of the Neapolitan Rhapsody of 1962, I am reminded of Chris Newman's comment a propos Debussy's Jeux: 'that piece hangs together like magic'. An inner logic, elusive and yet compelling, lends an unexpected substance to this work of modest dimensions.

This new CD is a further step in completing our view of this previously much neglected (even maligned) composer. Scott's great natural talent was apparent early on, of course, but true maturity was actually rather slow in coming, with the exception of a few major works like the fine Piano Sonata No. 1 and the Poems, much performed and praised by Percy Grainger. The optimal realization of Scott's musical personality begins with his middle and late works, where the best of the composer's personal fingerprints, idiosyncrasies and mannerisms all come together and really jell, transcending themselves. In the composer's own words: 'I plead guilty to not having "progressed" with the times; though I cannot thus plead, if I may say so, to not having progressed along the line and within the limits of my own particular idiom'.

In the tremendous Symphony No. 3, The Muses (1937) (dedicated to Beecham but never performed by him), Scott's earlier harmonic vocabulary, replete with unresolved seventhchords, is greatly expanded to include fresh fourth-based harmonies and polychords not unlike those later favoured by Schuman, Harris and Persichetti. There is also a fair amount of triadic harmony, often in parallel motion on fragments of the octatonic scale. These features will continue to play a role in subsequent works, forming the harmonic cornerstone of the late period. Scott must himself have realized the limitations of his earlier idiom, for he later stated: 'For the sake of variety and strength, it is necessary to have periods of discordance as a foil to the concordant parts... For my own part, I have not been afraid of discord, but neither have I been afraid of melody as a necessary contrast'. The first movement, 'Melpomene: Muse of Epic Poetry and Tragedy' contains some of the most exhilarating sea music this listener has ever heard, Bax, Bridge and Debussy notwithstanding. Scott's orchestration is everywhere skilful, always highly differentiated - a far cry from Grainger's complaint of 'Cyril's laziness in this regard', 
although this remark may have contained a grain of truth when Grainger made it, around 1910. Each of the remaining movements - the boisterous 'Thalia: Muse of Comedy and Merry Verse', the delicious 'Erato: Muse of Love and Poetry' and the exultant 'Terpsichore: Muse of Dance and Song' (with wordless choir!) - could serve as a major work in its own right.

Neptune (1933) is a revision of a work entitled Disaster at Sea, which gave a programmatic account of the sinking of the Titanic. In the composer's words, it depicts 'the mythological god who is at one moment benign and lenient, at another lashed to a destructive fury'. It was performed but once, in 1933. The work has a huge expressive range and is full of original ideas in orchestration (of which the opening pizzicato glissandi are just a foretaste).

The Piano Concerto No. 2 (1958) is finally available again. This is a profound work; its darkly glowing sound invites the listener to return to grasp its themes, at once simple and elusive. It is a fine example of music with a relatively simple surface but a complex background. Frank Martin, Tcherepnin and Jacques Hétu have also given us such inwardly searching, multi-dimensional works. Howard Shelley and the BBC Philharmonic under Martyn Brabbins are outstanding, as is to be expected. This listener is perhaps too accustomed to John Ogdon's premiere recording (on a Lyrita LP) from the 70s, finding the first movement a bit too brisk in the new interpretation. But this is a very minor quibble indeed. Perhaps the greatest work on this $\mathrm{CD}$, the Concerto is utterly personal, at once tragic and optimistic. It offers solace. Not a typical piano concerto; perhaps Glenn Gould would have approved of the work's avoidance of show-off virtuosity and 'competition' between soloist and orchestra. Ogdon obviously held it in high esteem.

To sum up: Scott has much to recommend him as a composer whose music rewards repeated hearings. There are melodic ideas of distinction, memorable yet never banal. His forms are new and original, spontaneous without sacrificing solidity. The orchestration is striking and personal. Above all, he has an individual voice transcending all influences. He was a man of wide-ranging interests and great spiritual awareness, which shows in the music.

We can look forward to hearing the new issue of Scott String Quartets, including works of his late period. ${ }^{9}$ Let us hope that more major works

\footnotetext{
9 Quartets Nos.1, 2 and 4 were recently issued on Dutton Epoch CDLX 7138 in performances by the Archaeus Quartet. Dutton have also issued Scott's Piano Qartet and Quintet, performed by the London Piano Quartet with Marilyn Taylor (vln) - (Ed).
}

by this very special British composer will soon be made available.

David Babcock

MAXWELL DAVIES: Miss Donnithorne's Maggot ${ }^{1}$; Eight Songs for a Mad King ${ }^{2}$. 1Jane Manning (sop), ${ }^{2}$ Kelvin Thomas (bar), Psappha. PSA CS 1001

MAXWELL DAVIES: Naxos Quartets Nos. 1 and 2. Maggini Quartet. Naxos 8.557396

The first release on Manchester-based ensemble Psappha's own label is a coupling of Peter Maxwell Davies's celebrated music-theatrical portraits of madness, Miss Donnithorne's Maggot and Eight Songs for a Mad King. Few readers will need an introduction to these works; for those that do, and even for those that don't, these new recordings are to be highly recommended.

Psappha, together with vocalists Jane Manning and Kelvin Thomas, have been performing these works - without a conductor - for at least four years prior to the recording. Although a significant proportion of the musical material demands unsynchronized parts (for which the absence of a conductor might be considered a bonus), the performances become all the more telling when precision of ensemble playing is called upon. The accuracy, the tightness of the ensemble, and above all the sheer energy of these readings on this disc bears ample witness to the successful collaboration between singers and ensemble.

In an enjoyable interview included on the CD, Davies tells of how the teacher of Roy Hart, the original soloist of Eight Songs, learnt to produce vocal multiphonics through imitating the sounds of the dying and wounded he heard on the battlefields of World War I. Hart and Davies's translation of noises made from physical torment into the depiction of mental torment is inspired. And, whilst it is tragic that Roy Hart did not live long enough to record his version, the absence of such a document can have a liberating effect. Such is the case with Kelvin Thomas's reading, in which his confrontation with the extraordinary demands of Davies's sometimes graphic notation gives rise to a compelling performance. Where the notation hints at chords, Thomas makes appropriate use of groaning, gargling and tortured moans that shockingly and vividly convey the dementia of George III. The virtuosic writing extends to the instrumental parts as well, handled with considerable élan by Psappha. But if the musical portrayal of madness were to be incoherent (as in the most literal depiction), it would soon become 
banal; thus the extreme vocal and instrumental writing is in fact balanced by music of considerable rigour. Combined with this, Thomas and Psappha assured dramatic shaping results in a constantly engaging performance.

The vocal writing in Miss Donnithorne's Maggot presents slightly different challenges to those of Eight Songs. Both push the soloists to extremes, but Miss Donnithorne's madness is less graphic. The generally more lyrical writing demands a greater range of characterization, which Jane Manning supplies in abundance. It is no mean task to convey on disc a character teetering on the brink of sanity, but in addition to this, Manning invests humour, tenderness and poignancy in the role. Once again, the instrumentalists are the equals of the vocalist: the frequent use of allusion and pastiche in both works seemingly leaves the ensemble untroubled as they switch between styles and modes of expression with disarming ease. The use of pastiche becomes particularly prominent towards the end of both works, but different musical ends. For King George, it culminates in his eventual capitulation to insanity and the pronouncement of his death. For Miss Donnithorne, it is an accompaniment to her increasing intoxication: though encouraging us to laugh, the music also engages our affections - we are touched by her despair. In this respect, Miss Donnithorne's Maggot is undoubtedly the more substantial work, even if it does not reach the more disturbing heights of its companion piece.

The decision by Naxos Records to commission ten string quartets from Maxwell Davies may have raised eyebrows in some quarters. No-one can question his industry, nor, since his first seven symphonies, his ability to conceive and realize an extended cycle. But the string quartet has not figured largely in his output hitherto: two 'Little Quartets', a 'Quartet Movement' and the more substantial String Quartet of 1961 are the only works in this genre. ${ }^{10}$ This does not appear to have posed any problems: the evidence on the first CD release points to an assured handling of the idiom, and augurs well for the complete cycle (to date, six of the ten quartets have been performed, but only two have been recorded). ${ }^{11}$

In the expressionistic, dramatic music theatre works of the late 1960s, Maxwell Davies frequently made use of allusion for ironic effect. In the quartets, the allusions are more subtle, and fulfil a different purpose, creating a complex network of cross-references. The more obvious

10 These four early quartet works are usefully collected on Metier MSV CD92055, performed by the Kreutzer Quartet - (Ed.).

11 As this review went to press, Naxos announced the issue of two more - Quartets Nos.3 and 4 (Naxos 8.557397) - (Ed.). connexions are the thematic links between movements, such as in the second quartet, when the material of the first subject of the first movement recurs in the later movements. There are also links between the quartets of the cycle: the first quartet ends practically mid-sentence, floating off into the stratosphere, in music to be taken up again in the third quartet.

Other allusive ghosts haunt the quartets: Haydn, Beethoven and Chopin inform the musical substance to various degrees, and more recent 20th-century precedents can be detected in the textures and sonorities. The spectre of the Classical string quartet, and particularly the sonata allegro, looms most strongly behind the first movements. Nevertheless, traditional gestures are subverted: repeats of expositions are promised, but left unfulfilled or distorted, and expected recapitulations are omitted. The result is ambiguous: one does not know if such distortions are ironic or a deferral of material until later in the cycle.

The quartets are by turns rugged, passionate, lyrical, mysterious and beautiful - and performed with conviction by the Maggini Quartet. Although neither of the quartets in this recording feels incomplete, it appears that each subsequent addition to the cycle will retrospectively alter our perception of the earlier members of the cycle. My impression, at this stage, is that the leanings towards the tonal centres of $\mathrm{F}$ and $\mathrm{D}$ will become increasingly important, but you can never tell with Max. One hopes that the complete cycle will enrich our understanding of these works. Until then, we have plenty to enjoy.

Edward Venn

BRUN: Symphony No. 3 in D minor. Moscow Symphony Orchestra c. Adriano. Sterling CDS-1059-2.

BLOCH: Helvetia; Suite for viola and orchestra; Suite Hébraïque for viola and orchestra. Gérard Caussé, (vla), Orchestre de la Suisse Romande c. Lior Shambadal. Cascavelle RSR 6170.

Fritz Brun's Third Symphony and Ernest Bloch's Helvetia are two very different orchestral works with a common source of inspiration: the Swiss artist Ferdinand Hodler (1853-1918). Hodler's fame was at its height when he exhibited at the 1904 Vienna Secession - hence, perhaps, the use of his art to illustrate the cover of Peter Franklin's life of Mahler. Like Arnold Böcklin, but drawing more on French than on German or Italian models, Hodler went in for evocative Symbolist 
paintings of figures and landscapes. A typical view of the Bernese Oberland, the Alps wreathed in vigorous swirls of cloud and light, appears on the cover of Sterling's Fritz Brun CD. It was, in fact, a Hodler painting of the Jungfrau as seen from Mürren which Brun named to the conductor Hermann Scherchen in connexion with his hour-long Third Symphony (1919). 'Autumn, bad weather, the picture inspired me, although secondarily. The first impression was the mountain itself, holding me in its clutches.'

In contrast to this on-the-spot musicalization, Bloch's continuous 'symphonic fresco' Helvetia was composed in San Francisco in 1929, several years after America and more than a decade after his Israel symphony. The sub-title reads 'Le Pays des Montagnes et son Peuple', and Bloch dedicated the work 'to all lovers of mountains and freedom, and in memory of Ferdinand Hodler'. Bloch's Hodler is the painter of the Alps but also of historical frescoes and the designer of a Swiss bank-note (using both his wife and his Parisian mistress as models for Helvetia).

Can stylistic parallels be drawn between artists and composers? One might venture to say that Brun's linear technique has affinities with Hodler's. Whereas Bloch, in Helvetia, was cultivating the Straussian tone poem, Brun sits firmly in the Brahms-Bruckner tradition, although there are features of his Third that set him apart. In his painstakingly researched booklet notes, Adriano defines these features as 'almost atonal and very dramatic, harsh sounding sections, full of syncopated chords and shifting chains of "rustling" or "gargling" notes (subdivided into different groupings of short note values), proceeding either in unison, in octaves, or in parallel and irregular intervals'. A three-note motif is the 'spark igniting the thematic material' of the elemental first movement. The epic strain vies with more intimate and peaceable moods; in its confrontation of man and nature, this music brings Vaughan Williams to mind.

Despite its overall length, Brun's Third Symphony consists of three movements, not four. The central movement comprises a set of six variations on a Swiss-Italian Epiphany carol. Adriano argues that the elaborate final variations (headed Sostenuto and Adagio affettuoso) might be treated as a self-contained slow movement. With its duet for solo cellos, the Adagio affettuoso presents a small masterpiece of instrumental lyricism. Here the composer acknowledged a debt to Berlioz. The final movement, in D major - a brighter though similarly craggy companion to the first constitutes a potent demonstration of Brun's

\section{MUSICIANS BENEVOLENT FUND}

\section{listening to musicians - responding to their needs}

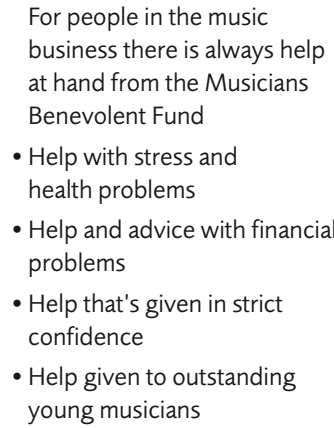

For people in the music business there is always help at hand from the Musicians Benevolent Fund

- Help with stress and health problems

- Help and advice with financia problems

- Help that's given in strict confidence

- Help given to outstanding young musicians

We operate throughout England, Scotland, Wales and the whole of Ireland If you or someone you know needs our help, please contact: Musicians Benevolent Fund 16 Ogle Street, London W1W 6JA

Telephone: 02076364481 Facsimile: 02076374307 email: info@mbf.org.uk website: www.mbf.org.uk Reg. Charity No. 228089 
contrapuntal art. Brun shows a Brahms-like restraint in his orchestration; its contrabassoon and four horns seem especially Brahmsian. From his Russian players Adriano elicits an intensely vivid and cohesive performance, delectably filigrane within the variations.

For their part, the Suisse Romande Orchestra under Lior Shambadal positively revel in the colours of Bloch's Helvetia. For a work lasting under 25 minutes, the scoring can only be described as extravagant: quadruple woodwind (including cor anglais, bass clarinet and contrabassoon), six horns, four trumpets, three trombones, tuba, a variety of percussion, celesta, two harps, plus strings. Emotionally, too, Bloch's music goes gorgeously over the top in its celebration of an ancient Swiss victory. But unlike the '1812', or for that matter the William Tell overture, it ends as poetically as it begins.

Bloch provided the following Romantic programme:

I. The Mountain itself, its mystery, its rocks and its forests. II. Dawn, the awakening of the Mountain and of men. III. The "Landsgemeinde", the open-air gathering where events are discussed. With dignity but tragically, the "Elders" announce that "the Fatherland is in danger". IV. But suddenly the people rise up. Their mountains shall not be enslaved. And then a true medieval battle erupts. It ends in Victory, which I have symbolized through an old Genevan song, "Cé qué lé no" (He who is on high). V. Epilogue. The Mountain is liberated, serene again, as after a storm.

Comparisons? The middle section includes a Raffish (rather than raffish) march and a Mahlerian wind chorale. There are reminiscences of Bloch's own early C sharp minor Symphony (the first sketches for Helvetia date from around the turn of the century). There is also a foretaste of the more elevated stretches of his 1938 Violin Concerto. And in the dramatic sections, the sheer energy of the writing recalls Carl Nielsen. Helvetia is well complemented on the present $\mathrm{CD}$ by Bloch's Suite for Viola and Suite Hébraïque, each in the version with orchestra.

Peter Palmer

PĒTERIS VASKS: Violin Concerto Distant Light ${ }^{1}$; Musica dolorosa; Viatore. ${ }^{1}$ Katarina Andreasson (vln and leader), Swedish Chamber Orchestra. BIS-CD-1150.

As a former double bass player with the Lithuanian Philharmonic Orchestra, the Latvian Chamber Orchestra and the Latvian Radio and Television orchestra, it is perhaps not surprising that Pēteris Vasks feels a special affinity with strings. In addition to the three works featured on this new BIS CD - all written for string orchestra other works composed for this medium include Cantabile (1979), Voices (1991), Musica adventus (1995-96), Adagio (1995-96) and the four string quartets.

Vasks describes the violin concerto Distant Light (1997), commissioned by the Salzburg Festival, as 'a concerto, in single-movement form, with contrasting episodes and three cadenzas for the soloist. A song, coming from silence and floating away into silence, full of idealism and love, at times melancholy and dramatic.' Despite its loose, episodic structure the work hangs together surprisingly well, due in no small part to the central solo role of Katarina Andreasson. Andreasson carries off the solo part with great aplomb, making light of any technical difficulties (glissandos, double-stopping) and playing with great intensity and luminosity of tone in the work's numerous cantabile passages so beloved by the composer.

Speaking about Musica dolorosa, Vasks has stated that 'I have always dreamed that my music - comforting and thought-provoking as it is would be heard where people were unhappy: in hospitals and prisons, in crowded trains and buses ... My music is intended for a large number of people, not just for the audiences at concert halls' (perhaps London Underground could look into the possibility of having the disc on repeat play). The earliest of the works on the disc - Vasks composed it in 1983 as a requiem for his sister - Musica dolorosa possesses a singular, perfectly fashioned beauty. Constructed from the very simplest of materials (pedal points, obsessively repeating pitches and, once again, the almost thematic use of the glissando) the work nevertheless builds to a densely argued and forceful climax. Taking on the key solo cello part, Mats Levin is an assured and big-toned soloist.

The disc also presents the world première recording of Viatore ('The Wanderer'), composed in 2001. Its musical material, alternating a cantabile section played first by cellos and divisi double basses with a 51-bar ritornello, contains strong echoes of the music of Arvo Pärt and of and one work - Tabula rasa - in particular. Viatore's striking ritornello passages, with their slight heterophonic variations and registral descents/ascents, especially call to mind Tabula rasa's vigorous opening movement, Ludus. Similarly, the ethereal glissando at the end of Viatore bears a striking similarity to the Pärtian practice of a work slowly unwinding into silence and reverberating beyond the final note. 
All three works, recorded in the presence of the composer in the first-rate acoustic of Sweden's Örebro Concert Hall, receive committed, crisply articulated performances by Scandinavia's only full-time chamber orchestra, the Swedish Chamber Orchestra.

Peter Quinn

CHINARY UNG: Spiral VI' ${ }^{1}$ Seven Mirrors' ${ }^{2}$; Grand Alap ${ }^{3}$; Grand Spiral ('Desert Flowers Bloom') ${ }^{4}{ }^{1}$ Quake, ${ }^{2}$ Gloria Cheng (pno), ${ }^{3}$ Walter Gray (vc), Rob Tucker (perc). La Jolla Symphony Orchestra c. Harvey Sollberger. New World 80619-2.

The music of the Far East has long exercised a fascination for European and American composers, so it was inevitable that composers of Far Eastern ethnic origin would in turn be influenced by Western traditional forms. From the concertos-by-committee that came into view in the West after the Cultural Revolution in China to the delicate beauty of Takemitsu's later output, East Asian music written to synthesize the conventions of East and West has increasingly made its presence felt in the concert hall and on disc. Not surprisingly, composers in the cultural melting-pot of the United States have represented the vanguard of the West's like-minded efforts in response, whether native-born (such as the late Lou Harrison) or émigrés like Tan Dun or Bright Sheng, both born in China and now creating enviable international reputations.

Chinary Ung (b. 1942) is unusual in this respect in being of neither Chinese nor Japanese descent. He is Cambodian, but emigrated to the USA in 1964. After graduating from the Manhattan School of Music and Columbia University (his teachers along the way included Chou Wenchung and, at Tanglewood, George Crumb), Ung began a distinguished teaching career at several colleges and universities in the US, slowly migrating westwards until arriving at the University of California in San Diego, where he is currently in his tenth year. A naturalized American, he was apparently the first US composer to receive the Grawemeyer Award, for his orchestral tone poem Inner Voices (1986) in 1989. This work was commissioned by the Philadelphia Orchestra shortly after Ung had broken a self-imposed exile from composition, from 1974 to 1985, during which he seems to have turned his back on Western avant-garderie and gone back to his roots. The fruits of his researches into Cambodian music and their impact on his style can be heard in Spiral, a trio for piano, cello and percussion recorded by the Aequalis Trio in 1991 for New World (80412-2), as well as on the current New World new disc devoted entirely to his music. ${ }^{12}$

Some of the compositional concerns and traits in Spiral are clearly audible on the new disc, not least in that two works have similar titles: Spiral VI (1992), a beguiling single-movement quartet for violin, cello, clarinet and piano, and the orchestral Grand Spiral ('Desert Flowers Bloom') from 1991. Ung has remarked: 'If East is yellow and West is blue, then my music is green'. Spiral VI is positively emerald, in that case: its soulful Asian melodies merge seamlessly into an evocative, mid-European sound world that recalls a wealth of musics from the early decades of the last century. Indeed, there is much about Ung's music that suggests what Western Classical music from a Cambodian might have sounded like in, say, the 1910 s and 1920s. Yet there is nothing archaic or backward-looking in Ung's musical persona; the harmonies are piquantly late-20th-century and the fantasia-like internal processes are modern and effortlessly developmental. There is also a very clear expressive focus throughout each of the compositions here, from the initial gesture often a held chord and a set of repeated notes followed by the primary intervals the piece is constructed from - to the usually gentle close. What occurs between, however, is very different from work to work.

This is most obviously noticeable in the large piano suite that gives the album its title, Seven Mirrors (1997). In the booklet, John Kays speaks of how its familiar 'piano gestures reflect postmodern characteristics that prevailed in the last quarter of the twentieth century'. Ung, as a good teacher, would undoubtedly have been aware of the trends around him, but it could also be that his style is characteristically a little outside of time,

\footnotetext{
12 The other works on New World 80412-2 are: Mario Davidovsky's ground-breaking Synchronism No. 6 for piano \& electronic sounds; Rand Steiger's engaging Trio in Memoriam (Paul Fromm); Miriam Gideon's wonderful Cello Sonata; and Martin Brody's Commedia. The performances of all these works are very fine, the result of good preparation in live performance and sympathy with the very diverse styles involved. The repertoire selected is not entirely random, either. Ung studied with Davidovsky, who in turn had been a pupil of Milton Babbitt, who was a fellow student with Gideon of Roger Sessions. New World's sound is very good, also. Ung's discography is fairly modest but includes several works issued on various CRI discs (e.g. SD-363 and SD-487) but collected later onto CRI SD-710. These works include the symphonic band original of Grand Spiral, two versions of Khse Buon (also available on Koch 37464-2), the early Mohori (1974) and Tall Wind (1970), and Spiral II. The Grawemeyer Award-winning Inner Voices appeared on Argo 444 560-2, in a performance by the American Composers Orchestra conducted by Dennis Russell Davies. And coupled with Lou Harrison's Suite for strings and McPhee's seminal Tabuh-Tabuhan.
} 
reflecting the Asian side of his sensibilities, or at least less concerned with questions of postmodernism than other American composers. I would argue that the style of Seven Mirrors - very different to those of the couplings - arises primarily from its extra-musical concerns with the poetry of Jelaluddin Rumi and Rabindranath Tagore: especially of the latter's Song Offerings, which colours the opening span, 'A Window in the Sky' and the central 'Laughter passes over the Earth'. Seven Mirrors is best thought of as a set of preludes or studies, demanding technically for the pianist - but ably expressed here by Gloria Cheng - which follow on from Debussy in being such perfectly realized miniatures, without Skryabin's floridity. Ung has said how he often composes from the middle outwards, and this suite seems to be no exception. For example, the second movement, 'Dotted Path', sounds as much a consequence of 'Laughter passes over the Earth' (the first to be written) as does the penultimate 'Tattooing Space-Time'. Only in the brilliant, final 'Flying Mirrors' is there an audible sense of a section destined to close the whole.

If Seven Mirrors holds more to the traditional Western side of Ung's musical make-up, in Grand Alap $(1996)^{13}$ we are in a very different part of the world and time. It is particularly instructive to compare this single-span work with the opening movement of the suite: the subtitle of the one being the main title of the other and both derived from Tagore, yet they feel entirely different. In Grand Alap, a bracing duo for amplified cello and a battery of percussion, what sound like more traditional Asian musical sounds rub shoulders with gestures not uncommon in more avantgarde Western scores, such as the syllabic vocalizations of the two performers. The net effect of this, however, is a music that is surprisingly contemplative, even by Ung's standards. While the opening section is turbulent, the main span is quiet and mesmeric, seeming to stretch time as it approaches its nicely inevitable conclusion. Another metaphor might be of a river winding - but never simply meandering through a reed bed to the sea. Although at first hearing this is the work that strives the least to ingratiate itself upon the Western ear, Grand Alap is perhaps the most sheerly fascinating of the four under consideration: Walter Gray (cellist in the Quake ensemble) and Rob Tucker provide an excellent account. One quibble, though: Ung directs that the duo should comprise one male and one female player.

Grand Spiral, by contrast, is perhaps closer to what one might expect of a work merging Asian and Western musics. Astonishingly, given its assurance in handling the ensemble, it was only Ung's second score for full orchestra (Inner Voices being the first), although he may have benefited from the experience of writing originally for a symphonic wind band. Grand Spiral is also the most immediate in appeal of the works here, though it creates a rather different impression to the chamber pieces, which have a common orchestral bigness about their sound even though employing only a few players. Harvey Sollberger directs a solid performance, but it is clear that the La Jolla Symphony Orchestra, recorded here at a live concert in June 2002, were not entirely within their comfort zone with the idiom. This results in some tentative passages, but ironically these help to illuminate the music's inner workings and individual lines. The sound is clear, if with necessarily a very different perspective to the instrumental and chamber pieces, which were recorded all together in the following November. Completed by a wonderful cover photograph of Angkor Wat, this is a splendid disc, heartily recommended. 